\title{
Ornithine Carbamoyltransferase, Mitochondrial
}

National Cancer Institute

\section{Source}

National Cancer Institute. Ornithine Carbamoyltransferase, Mitochondrial. NCI

Thesaurus. Code C75884.

Ornithine carbamoyltransferase, mitochondrial (354 aa, $40 \mathrm{kDa}$ ) is encoded by the human OTC gene. This protein plays a role in the metabolism of ornithine. 